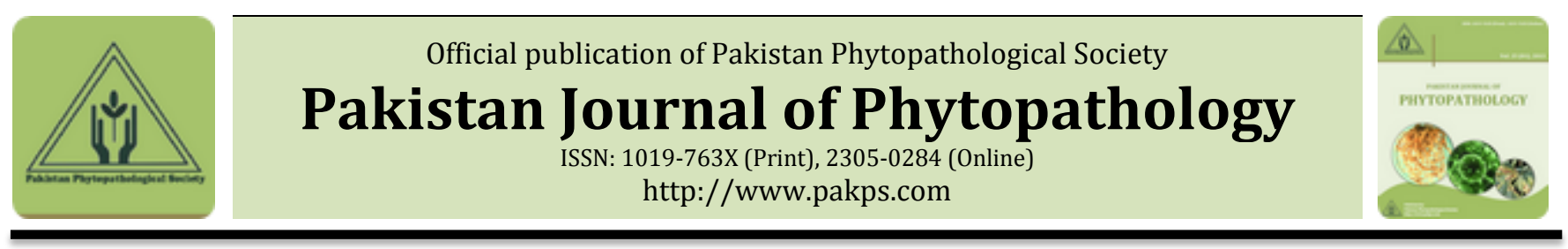

\title{
SEASONAL FLUCTUATION OF ASIAN CITRUS PSYLLA POPULATIONS IN THE CITRUS ORCHARDS INFECTED WITH HUANGLONGBING IN SARGODHA, PAKISTAN
}

\author{
aYasir Iftikhar*, bImran U. Haq, aWaqas Raza, cMuhammad I. Ullah, cSajjad Ali, dFahad N. Khoso, \\ eMustansar Mubeen \\ ${ }^{a}$ Department of Plant Pathology, University College of Agriculture, University of Sargodha, Sargodha-40100, Pakistan. \\ ${ }^{b}$ Department of Plant Pathology, University of Agriculture, Faisalabad, Pakistan. \\ 'Department of Entomology, University College of Agriculture, University of Sargodha, Sargodha-40100, Pakistan. \\ ${ }^{d}$ Department of Entomology, Sindh Agriculture University Tandojam, Pakistan. \\ eState Key Laboratory of Agricultural Microbiology and Key Laboratory of Plant Pathology of Hubel Province, Huazhong \\ Agricultural University, Wuhan 430070, China.
}

\section{A B S T R A C T}

A study on seasonal fluctuation in Citrus psylla (Diaphorina citri) (CP) population in citrus orchards infected with Huanglongbing was carried out in relation to environmental factors in six tehsils of Sargodha district. The population of citrus psylla was reached to the peak twice in a year. Young flushes favored the build-up in psylla population. Minimum temperature and rainfall had highly significant correlation with build-up in population of citrus psylla in all the six tehsils of Sargodha. Although, high temperature also favored the high population of citrus psylla in two tehsils. August and mid-March to April were the two times when population of citrus psylla reached to the peak. Therefore, an integrated management strategy can be formulated with this study that will not only help in reducing the HLB incidence but also increase in citrus production.

Keywords: Citrus, Greening disease, Citrus Psylla, Environmental factors

\section{INTRODUCTION}

Citrus orchards are vulnerable to many diseases, insect pests and abiotic stresses. Citrus greening disease (CGD), also named as Huanglongbing (HLB) has become one of the most devastating and widely distributed diseases in citrus groves (Batool et al., 2007; Saifullah et al., 2015). CGD is caused by a phloem-limited unculture-able gram negative bacterium known as Candidatus Liberibacter (Ca. L). The bacterium cell is bounded with double layer membrane. Three major strains of this bacterium, Asiaticus, Africanus and Americanus have been characterized based on environmental conditions, insect vector and genetic analysis (Garnier et al., 2000; Brlansky and Rogers, 2007; Coletta-Filho et al., 2004). The bacterium is transmitted by insect vector, Psyllids. Two species of CP, Diaphorina citri and Trioza erytreae, have been known as potent vectors of bacterial strains

* Corresponding Author:

Email: yasiriftikharpp@gmail.com

(C) 2017 Pak. J. Phytopathol. All rights reserved. such as Asiaticus, Americanus and Africanus, respectively (Manjunath et al., 2008). CP damages the citrus plants directly and indirectly as well. Nymphs of citrus psylla that inhabit new growth and adults suck the sap causing curling of leaves, defoliation, and heavy flower drop affecting the fruit set severely and even causing death of the branches from tip to downwards. Capoor et al., (1974) found the low percentage transmission of CGD through psyllids in a minimum infection feeding time of 15 minutes. Electron microscopy, monoclonal antibodies and several PCR methods have been found efficient way for detection of the pathogen in the host and vector. The pathogen detection system is very useful to produce disease-free citrus plants (Nageswara-Rao et al., 2013; Iftikhar et al., 2016).

Environmental factors influence the development of $D$. citri population (Aubert, 1987). Fluctuations in population of psyllids are closely related with the occurrence of new young flush and environmental 
factors (Hall and Albrigo, 2007). Therefore, it is necessary to understand the dynamics of the population build-up of this vector for effective management practices. The present study was carried out to monitor the effect of environmental factors on citrus psylla population changes in Sargodha district.

\section{MATERIALS AND METHODS}

A survey was carried out in six tehsils (Sargodha, Bhalwal, Shahpur, Sahiwal, Sillanwali and Kot Momin) of Sargodha district. Orchards were randomly selected however sites with multiple age groups of kinnow orchards were preferred. Symptomology for identification of CGD in the field was the basic criterion for selection of orchards followed by quick indexing of CGD prior to monitor the insect vector (Saifullah et al., 2015).

Monitoring of Insect Vector: Population dynamics of citrus psylla was recorded in the selected citrus orchards during 2013 to 2014. Psylla population was calculated on number of adults per leaf. Five sites in an orchard were selected for insect population counting. A single tree under observation was divided into four equal parts by hypothetical lines and 6-7 leaves on each side with apparently more number of psylla were selected. The number of psylla adults were counted and recorded. The trees and branches were tagged for the future readings throughout the study. Data was recorded fortnightly (Saifullah et al., 2015).

Collection of Environmental data: Data of environmental factors such as maximum and minimum temperature, rain fall and relative humidity was recorded from the meteorological office during the season. The data was statistically analyzed in relation to population dynamics of citrus psylla. The prevailing environmental conditions during the study period are shown graphically (Figure 1). Data of population changes was calculated at an interval of fifteen days throughout the year starting from August 2013 to May 2014 and was correlated with environmental data using the " $R$ " software.

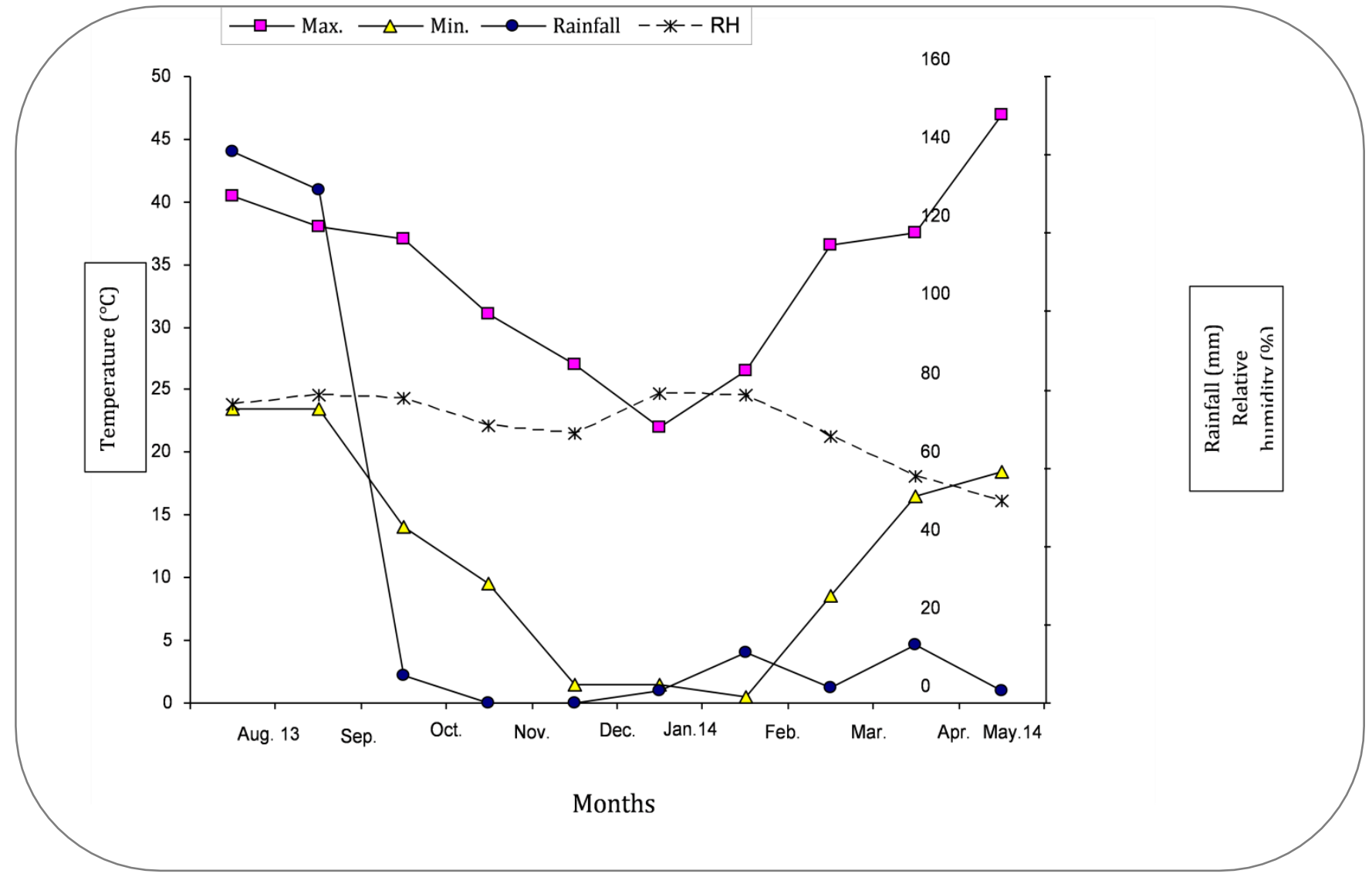

Figure 1. Meteorological data from August 2013-June 2014

RESULTS

The CP population was not high during the months of December and January. The lowest population was recorded in December. Build-up in psylla population was observed in mid-March and April and peak population was found in August in all tehsils of 
Sargodha district. There was no significant correlation between psylla population build-up and relative humidity. There was maximum relative humidity in middle of January and second time in middle of September where the population varies greatly in these two months. May-June was found with maximum high temperature (Figure 1). Psylla population found low in these months. Psylla population reached to the peaks twice during the season, once in August and then in April. Low or very little psylla population was found in the months of December to February and May-June (Figure 2).

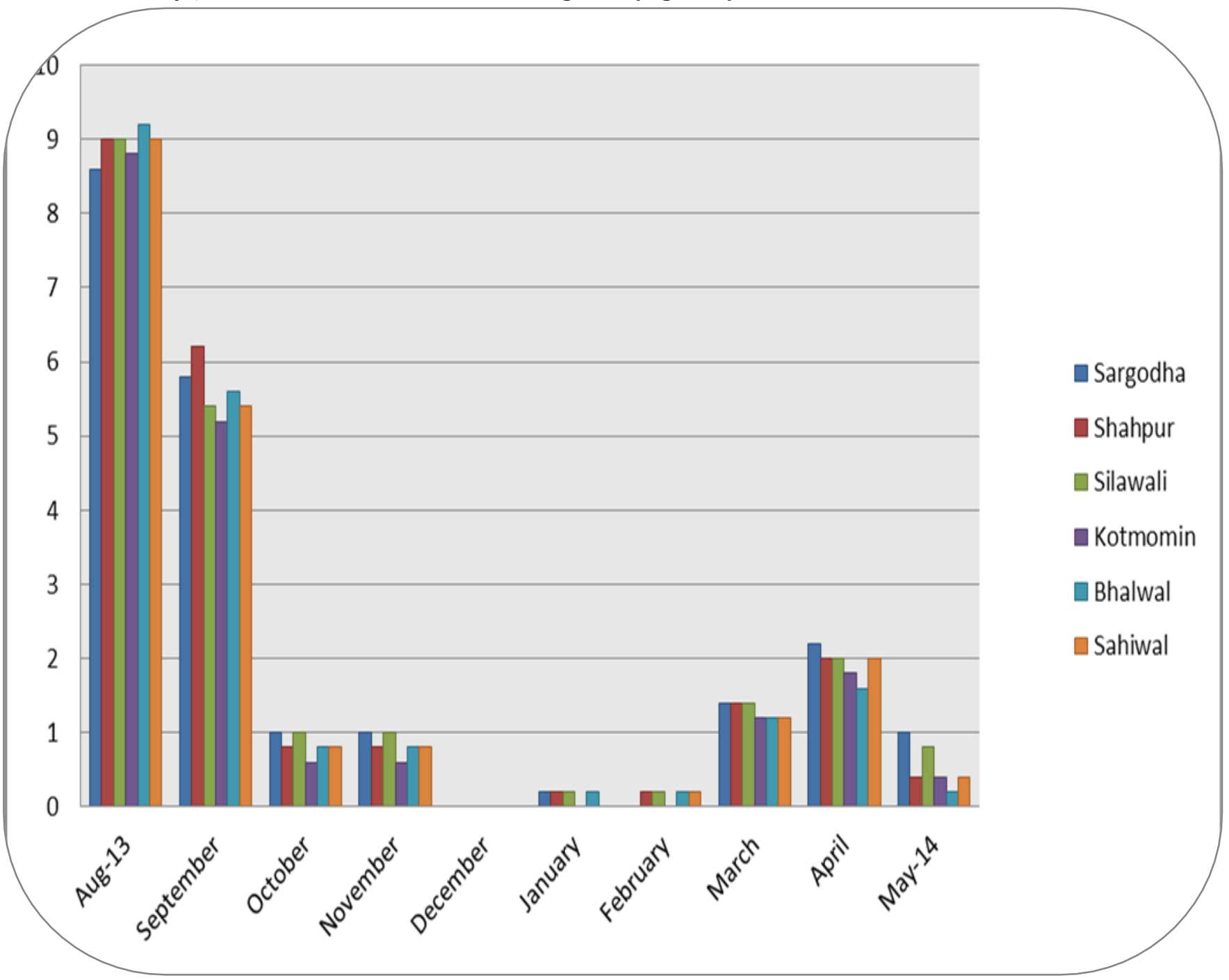

Figure 2. Citrus psylla population/leaf recorded during whole study period

Correlation between Citrus Psylla Population and Environmental Factors

Population of citrus psylla in relation to temperature: Environmental data recorded in all tehsils of Sargodha district showed that maximum and minimum temperatures and rainfall had significant correlation with fluctuation in CP population. Rainfall and minimum temperature were significantly correlated with population of $\mathrm{CP}$ in all the tehsil of Sargodha district while maximum temperature had significant correlation in two tehsils (Sargodha and
Sillanwali). Relative humidity had non-significant correlation with build-up in psylla population in all the tehsils (Table 1). The rainfall pattern of the Sargodha region depicted that during December no rainfall was recorded where as high rainfall was recorded in moon soon season during July-August (Figure 1). Minimum psylla population was recorded in December whereas maximum population was recorded in August soon after the moon soon season (Figure 2). There was a highly significant and positive correlation found between CP population and rainfall. 
Table 1. Correlation between citrus psylla population and different environmental factors in all tehsils of Sargodha

\begin{tabular}{lcclc}
\hline Tehsil & Rainfall $(\mathrm{mm})$ & Maximum Temperature $\left({ }^{\circ} \mathrm{C}\right)$ & $\begin{array}{l}\text { Minimum Temperature } \\
\left({ }^{\circ} \mathrm{C}\right)\end{array}$ & $\begin{array}{l}\text { Relative Humidity } \\
(\%)\end{array}$ \\
\hline Sargodha & $0.919^{* *}$ & $0.656^{*}$ & $0.914^{* *}$ & 0.066 \\
& 0.000 & 0.039 & 0.000 & 0.857 \\
Shahpur & $0.939^{* *}$ & 0.606 & $0.885^{* *}$ & 0.153 \\
& 0.000 & 0.064 & 0.001 & 0.673 \\
Sillanwali & $0.916^{* *}$ & $0.641^{*}$ & $0.896^{* *}$ & 0.105 \\
& 0.000 & 0.046 & 0.000 & 0.772 \\
Kotmomin & $0.922^{* *}$ & 0.625 & $0.885^{* *}$ & 0.119 \\
& 0.000 & 0.053 & 0.001 & 0.743 \\
Bhalwal & $0.937^{* *}$ & 0.587 & $0.865^{* *}$ & 0.178 \\
& 0.000 & 0.074 & 0.001 & 0.623 \\
Sahiwal & $0.923^{* *}$ & 0.620 & $0.885^{* *}$ & 0.129 \\
& 0.000 & 0.056 & 0.001 & 0.722 \\
Overall & $0.927^{* *}$ & 0.623 & $0.889^{* *}$ & 0.126 \\
& 0.000 & 0.054 & 0.001 & 0.729 \\
\hline
\end{tabular}

Upper values indicated Pearson's correlation coefficient; Lower values indicated level of significance at $\mathrm{P}=0.05 ._{-}{ }^{*}=$ Significant $(\mathrm{P}<0.05) ; * *=$ Highly significant $(\mathrm{P}<0.01)$

\section{DISCUSSION}

Candidatus liberibacter, the cause of Asian citrus greening is transmitted through Diaphorina citri. It is vegetatively propagated in nature (Batool et al., 2007). Population dynamics of $\mathrm{CP}$ were studied in relation to environmental conditions. Only rainfall and minimum temperature were significant contributor for build-up of its population because of new shoot sprouts served as main source of oviposition and feeding. It is citrus psylla population can be positively correlated to emergence of new flushes in citrus after the rainfall and change in temperature (Tsai et al., 2002). That's why citrus psylla population peaks were observed in August and MarchApril. Previous studies also showed the two peaks in citrus psylla population during a year (Ahmed et al., 2004; Wang et al., 2009). Although flushing shoots has a positive effect of the population of CP but environmental factors and natural enemies helps the fluctuation in their population throughout the year (Teck et al., 2011; Rogers et al., 2012). Sharma (2008) observed low population of adult CP in Dec-Jan, that was increased by the end of February. Our results were in accordance with the findings of Gupta (2000) and Ahmed et al., (2004). They observed the pest was active though out the year except December while its population peak was seen in the month of August. There was non-significant correlation of $\mathrm{CP}$ population with relative humidity. The results were in contradiction with Arora et al., (1997). A positive significant effect of relative humidity on citrus psylla populations was described by McFarland and Hoy
(2001) in Florida. It might be due to change in environmental conditions.

Normally, least levels of citrus psylla populations are observed in winter season. It is observed that citrus psylla population reached to almost zero level in December and January in Palai and Charbagh regions of Khyber Pakhton khwoa, Pakistan (Zeb et al., 2011). Young flush growth due to rainy season after the dry and humid weather are responsible for the boost up in citrus psylla population (Bove, 2006). The information can be used for the effective management practices for CP and CGD ultimately.

\section{REFERENCES}

Ahmed, S., N. Ahmad and R. R. Khan. 2004. Studies on Population Dynamics and Chemical Control of Citrus Psylla, Diaphorina Citri. Int. J. Agric. Biol. 6(6): 970-973.

Arora, P. K., S. K. Thind, S. I. K. Nirmaljit, Grewal and N. Kaur. 1997. Population dynamics of citrus psylla, Diaphorina citri Kuwayama on kinnow and mandarin in relation to temperature and relative humidity. Indian J. Ecol. 24(2): 179-183.

Aubert, B. 1987. Trioza erytreae del Guercio and Diaphorina citri Kuwayama (Homoptera: Psylloidea), the two vectors of citrus greening disease: Biological aspects and possible control strategies. Fruits, 42: 149-162.

Batool, A., Y. Iftikhar, S. M. Mughal, M. M. Khan, M. J. Jaskani, M. Abbas, and I. A. Khan. 2007. Citrus greening disease- a major cause of citrus decline 
in the world- a review. HORT. SCI. 34(4): 159166.

Bove, J. M. 2006. Huanglongbing: A destructive, newlyemerging, century-old disease of citrus. J. Plant Pathol. 88: 7-37.

Brlansky, R. H and M. E. Rogers. 2007. Citrus huanglongbing: Understanding the vectorpathogen interaction for disease management. Online. APSnet Features. doi: 10.1094/ APSnetFeature-2007-1207.

Capoor, S. P., D. G. Rao and S. M. Viswanath. 1974. Greening disease of citrus in the Deccan Trap Country and its relationship with the vector, Diaphorina citri Kuwayama. In Proc. 6th Conference of the International Organization of Citrus Virologists. Univ. California, Richmond. 43-49.

Coletta-Filho, H. D., M. L. P. N. Targon, M. A. Takita, J. D. De Negri, J. Jr. Pompeu, M. A. Machado and G. W. Muller. 2004. First report of the causal agent of Huanglongbing (Candidatus liberibacter asiaticus) in Brazil. Plant Dis. 88(12): 13821382.

Garnier, M., S. Jagoueix-Eveillard, P. R. Cronje, H. F. Le Roux and J. M. Bové. 2000. Genomic characterization of a liberibacter present in an ornamental rutaceous tree, Calodendrum capense, in the Western Cape Province of South Africa. Proposal of 'Candidatus liberibacter africanus subsp. capensis'. Int. J. Sys. Evol. Microb. 50(6): 2119-2125.

Gupta, D and R. Bhatia. 2000. Population dynamics of the citrus psylla, Diaphorina citri Kuwayama in lower hills of Himachal Pradesh. Pest Manag. Econo. Zoo. 8: 41-45.

Hall, D. G. and L. G. Albrigo. 2007. Estimating the relative abundance of flush shoots in citrus with implications on monitoring insects associated with flush. Horti. Sci. 42(2): 364-368.

Iftikhar, Y., S. Rauf, U. Shahzad, M. A. Zahid. 2016. Huanglongbing: Pathogen detection system for integrated disease management - A review. J. Saudi Soc. Agric. Sci. 15 (1): 1-11.

Manjunath, K. L., S. E. Halbert, C. Ramadugu, S. Webb and R. F. Lee. 2008. Detection of liberibacter asiaticus in Diaphorina citri and its importance in the management of citrus huanglongbing in Florida. Phytopathol. 98(4): 387-396.

McFarland, C. D and M. A. Hoy. 2001. Survival of Diaphorina citri (Homoptera: Psyllidae), and its two parasitoids, Tamarixia radiate (Hymenoptera: Eulophidae) and Diaphorencyrtus aligarhensis (Hymenoptera: Encyrtidae), under different relative humidities and temperature regimes. Florida Entomol. 84: 227-33.

Nageswara-Rao, M., M. Irey, S. M. Garnsey and S. Gowda. 2013. Candidate gene makers for Candidatus Liberibacter asiaticus for detecting citrus greening disease. J. Biosci. 38(2): 229-237.

Rogers, M. E., P. A. Stansly and L. L. Stelinski. 2012. Florida Citrus Pest Management Guide: Asian Citrus Psyllid and Citrus Leafminer. IFAS Extension Publication ENY-734. University of Florida, Gainesville, FL, USA.

Saifullah., I. Haq. I. Yasir, S. A. Khan, M. J. Jaskani, Samiullah and R. M. S. Tariq. 2015. Quick indexing of huanglongbing on the basis of symptomology and iodo-starch test in relation to environmental factors. Pak. J. Agric. Sci. 52(4): 1005-1009.

Sharma, D. R. 2008. Population dynamics in relation to abiotic factors and management of citrus psylla in Punjab. Indian J. Hort. 65: 417-422.

Teck, S. L., A. Fatimah, A. Beattie, R. K. Heng and W. S. King. 2011. Seasonal Population Dynamics of the Asian Citrus Psyllid, Diaphorina citri Kuwayama in Sarawak. American J. Agric. Biol. Sci. 6 (4): 527-535.

Tsai, J. H., J. J. Wang and Y. H. Liu. 2002. Seasonal abundance of the Asian Citrus Psyllid, Diaphorina citri (Homoptera: Psyllidae) in Southern Florida. Florida Entomol. 85(3): 446-451.

Wang, N., W. Li, M. Irey, G. Albrigo, K. Bo and J. S. Kim. 2009. Citrus huanlongbing. Tree for. sci. biotech. 3: 67-72.

Zeb, Q., I. Khan, M. Inayatullah, Y. Hayat, M. A. Khan, A. R. Saljoqi and M. A. Khan. 2011. Population dynamics of citrus whiteflies, aphids, citrus psylla leaf miner and their bio-control agents in Khyber Pakhtunkhwa. Sarhad J. Agric. 27(3): 451-457. 